\title{
Preface: Cladocera crustaceans: sentinels of environmental change
}

\author{
Hilde Eggermont • Koen Martens
}

Published online: 20 October 2011

(C) Springer Science+Business Media B.V. 2011

\section{Background}

Growing awareness of the negative impacts of global change urges scientists to look for adequate means to assess past and ongoing environmental change. The extent and dynamics of natural ecosystem variability is not yet fully clear, though understanding of this variability is crucial for predicting future trends (IPCC, 2007). Paleolimnological records holding valuable proxy information in the form of sediment features, geochemical records and micro- and macrofossil assemblages, can complement observational data by extending timescales, integrating sub-annual variability and expanding the range of sites that can be studied (Battarbee et al., 2005). Modern limnological time-series, though limited in space and time, can still add crucial information to these surveys. Similarly, in situ and laboratory experiments can complement paleolimnological approaches by improving our

Guest editors: H. Eggermont \& K. Martens / Cladocera as indicators of environmental change.

H. Eggermont $(\bowtie) \cdot$ K. Martens

Royal Belgian Institute of Natural Sciences, Freshwater

Biology, Vautierstraat 29, 1000 Brussels, Belgium

e-mail: hilde.eggermont@naturalsciences.be

\section{H. Eggermont · K. Martens}

Limnology Unit, Department of Biology,

Ghent University, K.L. Ledeganckstraat 35,

9000 Ghent, Belgium mechanistic understanding of the relationship between proxy indicators and their environment.

Cladocera (Crustacea: Branchiopoda; water fleas) play a key role in freshwater ecosystems because of their pivotal position in the food web, sandwiched between top-down regulators (fish and invertebrate predators) and bottom-up factors (phytoplankton). The intermediary position occupied by cladocerans underlies their significance for nutrient cycling in freshwaters (Järvinen \& Salonen, 1998; Urabe et al., 2002) and as sentinels of environmental change (Jeppesen et al., 2001; Korhola \& Rautio, 2001; Kurek et al., 2010). Subfossil cladocerans (typically Bosminidae, Chydoridae and Daphniidae) appear in lake sediments mainly in disarticulated body parts, such as head shields, carapaces and postabdomens, or as epphipia (a structure that protects diapausing eggs). The taxonomic composition of these remains has been used to track past changes in the environment, including eutrophication (Brodersen et al., 1998; Shumate et al., 2002; de Eylo et al., 2003; Davidson et al., 2007; Chen et al., 2010), acidification (Paterson, 1994; Jeziorski et al., 2008), lake water calcium decline (Jeziorski et al., 2008), lake levels (Korhola et al., 2000, 2005) and climate (Lotter et al., 2000; Kattel et al., 2008). In addition, the taxonomic composition of cladocerans shows a strong response to biotic factors that can vary with lake trophic state, such as fish density (Jeppesen et al., 1996, 2001; Finney et al., 2000) and submerged macrophytes (Davidson et al., 2007). Cladocera-based reconstructions have not remained qualitative only, but the strong link between cladoceran 
distribution and various environmental variables has led to the construction of so-called inference models (or transfer functions) now allowing for quantitative reconstruction of total phosphor (TP) (Brodersen et al., 1998; Amsinck et al., 2005; Chen et al., 2010), lake depth (Korhola et al., 2005; Nevalainen et al., 2011a, b) and temperature (Lotter et al., 1997; Korhola, 1999; Kattel et al., 2008). Resting eggs of the pelagic species of Daphnia, then again, have been applied to testing cause and effect relationships between past populations and paleolimnological inferences (Kerfoot et al., 1999; Amsinck et al., 2007). Because subfossil resting eggs are often viable for up to 100 years (Hairston et al., 1993) and provide sufficient quality and quantities of DNA for genetic analyses from even longer periods of time, resting egg banks also represent a unique biological archive to unravel ecological and evolutionary changes (Hairston et al., 1999; Brendonck \& De Meester, 2003). As such, paleogenetics of Daphnia resting eggs has proven its value in studies on microevolutionary changes in cladoceran populations (e.g., Cousyn et al., 2001; Limburg \& Weider, 2002), response of populations and communities to environmental change (e.g., Pollard et al., 2003; Brede et al., 2009), and invasion and/or recolonization dynamics (e.g., Duffy et al., 2000; Mergeay et al., 2006, 2007). Hence, over recent years cladoceran paleoecology has clearly grown to a mature research discipline, but significant challenges remain.

\section{Challenges in cladocera paleoecology}

Frey (1960) was, in many respects, a pioneer in recognising the utility of cladoceran remains in lake sediments as opposed to sampling extant populations that may show substantial variability in seasonal and annual abundance, in addition to habitat diversity. Methods for sampling Cladocera from lake sediments are now relatively standardised (Frey, 1986; Hann, 1989; Korhola \& Rautio, 2001; Szeroczyńska \& Sarmaja-Korjonen, 2007), but they are still being updated (e.g. Kurek et al. 2010). Also, available transfer functions are critically evaluated (e.g., Kattel et al., 2008) and new methodologies become available (e.g. Alexander \& Hotchkiss, 2010). Interpretation of the sedimentary cladoceran record is not straightforward, however, and the development of techniques for subfossil Cladocera research has clearly lagged behind other common paleolimnological indicators (e.g. diatoms, chironomids). Indeed, cladoceran paleoecology is still facing limitations related to taxonomic difficulties (Korosi et al., 2011), complex patterns of production and distribution (Kerfoot, 1981; Anneville et al., 2010), differential preservation of species and type of remains (Frey, 1986; Hann, 1989; Rautio et al., 2000; Kattel et al., 2007), and sedimentation dynamics. Efforts to improve the comparability of observational data and the paleolimnological record are therefore still needed (Battarbee, 2005). Furthermore, most of the published literature on (sub)-fossil Cladocera originates from Europe and North America (Korosi \& Smol, 2011), and only a small number focuses on tropical regions (e.g. Eggermont et al., 2008; Rull et al., 2008).

One approach to evaluate how well the sediment record reflects the living community is to sample live animals from various habitats within a lake, and to compare the species assemblages (plankton counts) with lake surface sediments (Rautio et al., 2000; Kattel et al., 2007; Nykänen et al., 2009). Such results have addressed the differential preservation of species (Alric \& Perga, 2011), as well as biases in a central lake core, attributable to transport processes from littoral source communities (Nykänen et al., 2009). Another approach is to sample less extensively in one lake, but to incorporate data from several lakes (Jeppesen et al., 2000; Davidson et al., 2007). Such studies have illustrated discrepancies as well as similarities between the contemporary community and fossil assemblages (Nykänen et al., 2009). Finally, studies quantifying the relationship between the production of remains and their deposition also yielded very valuable insights (Kerfoot 1981, 1995; Hall \& Yan, 1997; Nykänen et al., 2009). Yet, due to the heterogeneity of approaches used, and/or focus on different lake types and time windows, results of studies are not always readily comparable. Clearly, more taphonomic studies are needed to broaden our understanding of the picture provided by cladoceran fossil assemblages.

In light of global change impacts and mitigation, Cladocera-based reconstructions of climate are gaining increased attention. Besides methodological difficulties mentioned above, environmental changes that are not related to climate, such as eutrophication, acidification or habitat modification, can hamper Cladocerabased climate reconstruction (e.g. Sarmaja-Korjonen \& Hyvärinen, 1999; Duigan \& Birks, 2000; Hofmann, 
2003). Similarly, influence of regional temperature change on a local cladoceran fauna may be masked by their biotic response to variation in other (local) limnological factors driven by climate change (Battarbee et al., 2002). It may therefore be difficult or even impossible to separate many of the environmental signals from downcore data, but careful examination of the influence of all parameters on Cladocera-based reconstructions and multi-proxy approaches can bring some solace.

\section{Special issue content}

Several papers in this special issue aim at identifying environmental forcing factors affecting cladoceran distribution at various spatial scales, and as such they provide a better delineation of their ecological preferences and indicator value. For example, Nevalainen (2011) assessed the intra-lake variability in fossil cladoceran assemblages to identify habitat specificity of Cladocera in relation to local hydrology-related environmental factors. Similarly, Kultti et al. (2011) showed that the total number of chydorid ephippia increases along a climate gradient, and they used this relationship to create a novel method for paleotemperature reconstruction in Finnish cold-temperate environments. Rumes et al. (2011), then again, analysed the turnover of cladoceran species along several environmental gradients in a large set of Ugandan crater lakes to demonstrate their potential as biological indicators for water quality and ecosystem health in East Africa. Whereas the latter study focused on the Ugandan lowlands, Van Damme \& Eggermont (2011) addressed the ecology, biogeography and taxonomy of the Cladocera fauna in the Rwenzori Mountains (Uganda-D. R. Congo).

Taphonomic problems in cladoceran paleoecology are also dealt with in this issue. Alric \& Perga (2011) assessed the effect of production, sedimentation and taphonomic processes on the representativeness of fossil assemblages in terms of both species composition and size structure of pelagic communities by comparing fossil assemblages in sediment traps and modern cladoceran source communities in a subalpine lake.

This issue also tackles taxonomical issues. For example, Korosi et al. (2011) performed a detailed analysis of the postabdominal claws from several
Daphnia species in south-central Ontario, Canada (including claw length, width, curvature and spine/ spinule length) to determine whether subtle differences exist that can be used to aid taxonomic resolution within species complexes. Such advances in the taxonomic resolution of subfossils will allow researchers to address increasingly nuanced questions, and ultimately help to improve our understanding on how lakes change over time in response to complex multiple environmental stressors.

Aspects of quantitative Cladocera-based reconstructions are also examined here. For example, Davidson et al. (2011a) analysed cladoceran surface sediment assemblages from 53 lakes in Greenland with substantial variation in lake depth and fish abundance, and developed lake-depth transfer functions for various sets of lakes (i.e. with and/or without fish). As such, they were able to assess the degree to which variation in predation pressure can interfere with an empirical model based largely on an indirect relationship. Luoto et al. (2011) investigated the influence of hydrological variables and stream flow on quantitative Cladocera-based air temperature and water depth reconstructions. In doing so, they also addressed the issue of sampling point selection in down core paleolimnological studies. In the same context of lake level reconstruction, Siitonen et al. (2011) provided a Cladocera-based Holocene lakedepth reconstruction of a northern boreal lake in Finnish Lapland, and compared this with reconstructions based on other proxies, in order to evaluate the utility of Cladocera as single-used proxy.

Six papers in this special issue provide actual Cladocera-based reconstructions, and as such, validate the potential of subfossil Cladocera as sentinels of environmental change. Using the so-called 'topbottom' approach, Nevalainen et al. (2011a, b) compared contemporary and pre-industrial age (before 1850 AD) fossil assemblages of Cladocera in sediment cores from 25 lakes in the Italian and Swiss Alps to investigate the impact of mounting anthropogenic stresses over the past 150 years on community composition. Milecka et al. (2011) provided a paleoenvironmental record of lake and catchment changes in northern Poland during the Late Glacial and the beginning of the Holocene. Similarly, Kattel \& Sirocko (2011) examined the role of cladocera for reconstruction of the environmental, cultural and archaelogical development in the Eifel maar lakes 
region (West Germany) during the Late Glacial and Holocene periods; and Korponai et al. (2011a) analysed subfossil cladocera assemblages from Late Glacial/Preboreal sediments of Lake Brazi (a South Carpathian mountain lake) to trace the community response to rapid climatic warming that occurred during this period. Korponai et al. (2011b), then again, provided a Cladocera-based reconstruction of trophic states in Lake Balaton (Hungary) over the last several thousand years; and López-Blanco et al. (2011) presents some interesting data on Cladocera species shifts resulting from hydrological alterations caused by a canal in Lake El Tobar, Spain.

This issue also illustrates the usefulness of combining paleo- and neo-ecological observational studies, as well as short-term experiments in assessing the response of Cladocera to environmental change. Fischer et al. (2011) showed that Daphnia abundance can serve as a powerful sentinel to climate change in alpine lakes of the Rocky Mountains.

Finally, using examples from Danish, Estonian and UK lakes, Jeppesen et al. (2011) showed in their review paper that zooplankton (sampled from the sediment and water) have a strong indicator value. As such, the authors plead for including zooplankton in the ecological quality assessment of lakes according to the European Water Framework Directive (WFD; European Union, 2000). Within the same WFD, Davidson et al. (2011b) compared plant macrofossil and subfossil Cladocera assemblages from 21 sediment cores spanning the last two to three centuries, and further confirm the (paleo)indicator value of Cladocera in shallow lakes.

In summary, the articles presented in this Special Issue are intended to explore and highlight the indicator value of Cladoceran, using both modern and paleolimnological approaches. Although it is clear that more research is needed to validate results in a geographically larger context, this issue definitely brings out research areas which will prove fruitful for future investigation.

\section{References}

Alexander, M. L. \& S. C. Hotchkiss, 2010. Bosmina remains in lake sediments as indicators of zooplankton community composition. Journal of Paleolimnology 43: 51-59.
Alric, B. \& M.-E. Perga, 2011. Effects of production, sedimentation and taphonomic processes on the composition and size structure of sedimenting cladoceran remains in a deep subalpine lake: paleo-ecological implications. Hydrobiologia. doi:10.1007/s10750-011-0868-0.

Amsinck, S. L., E. Jeppesen \& F. Landkildehus, 2005. Relationships between environmental variables and zooplankton subfossils in the surface sediments of 36 shallow coastal brackish lakes with special emphasis on the role of fish. Journal of Paleolimnology 33: 39-51.

Amsinck, S. L., E. Jeppesen \& D. Verschuren, 2007. Use of cladocera resting eggs to trace climate-driven and anthropogenic changes in aquatic ecosystems. In Alekseev, V., B. De Stasio \& J. J. Gilbert (eds), Diapause in Aquatic Invertebrates: Theory and Human Use. Kluwer, Dordrecht: 135-157.

Anneville, O., J. C. Molinero, S. Souissi \& D. Gerdeaux, 2010. Seasonal, interannual variability of Cladocera communities in two peri-alpine lakes: uncoupled response to the 2003 heatwave. Journal of Plankton Research 32: 913-925.

Battarbee, R. W., R. Thompson, J. Catalan, J. A. Grytnes \& H. J. B. Birks, 2002. Climate variability and ecosystem dynamics of remote alpine and arctic lakes: the MOLAR project. Journal of Paleolimnology 28: 1-6.

Battarbee, R. W., N. J. Anderson, E. Jeppesen \& P. Leavitt, 2005. Combining paleolimnological and limnological approaches in assessing lake ecosystem response to nutrient reduction. Freshwater Biology 50: 1772-1780.

Brede, N., C. Sandrock, D. Straile, P. Spaak, T. Jankowski, B. Streit \& K. Schwenk, 2009. The impact of human-made ecological changes on the genetic architecture of Daphnia species. Proceedings of the National Academie of Sciences of the United States of America 106: 4758-4763.

Brendonck, L. \& L. De Meester, 2003. Egg banks in freshwater zooplankton: evolutionary and ecological archives in the sediment. Hydrobiologia 491: 65-84.

Brodersen, K. P., M. C. Whiteside \& C. Lindegaard, 1998. Reconstruction of trophic state in Danish lakes using subfossil chydorid (Cladocera) assemblages. Canadian Journal of Fisheries and Aquatic Sciences 55: 1093-1103.

Chen, G., C. Dalton \& D. Taylor, 2010. Cladocera as indicators of trophic state in Irish lakes. Journal of Paleolimnology 44: 465-481.

Cousyn, C., L. De Meester, J. K. Colbourne, L. Brendonck, D. Verschuren \& F. Volckaert, 2001. Rapid, local adaptation of zooplankton behavior to changes in predation pressure in the absence of neutral genetic changes. Proceedings of the National Academy of Sciences of the United States of America 98: 6256-6260.

Davidson, T. A., C. D. Sayer, M. R. Perrow, M. Bramm \& E. Jeppesen, 2007. Are the controls of species composition similar for contemporary and sub-fossil cladoceran assemblages? A study of 39 shallow lakes of contrasting trophic status. Journal of Paleolimnology 38: 117-134.

Davidson, T. A., H. Bennion, E. Jeppesen, G. H. Clarke, C. D. Sayer, D. Morley, B. V. Odgaard, P. Rasmussen, R. Rawcliffe, J. Salgado, G. L. Simpson \& S. L. Amsinck, 2011a. The role of cladocerans in tracking long-term change in shallow lake trophic status. Hydrobiologia. doi: 10.1007/s10750-011-0851-9. 
Davidson, T. A., S. L. Amsinck, O. Bennike, K. Christoffersen, F. Landkildehus, T. L. Lauridsen \& E. Jeppesen, 2011b. Inferring a single variable from assemblages with multiple controls: getting into deep water with cladoceran lakedepth transfer functions. Hydrobiologia. doi:10.1007/ s10750-011-0901-3.

de Eylo, E., K. Irvine, F. Garcia-Criado, M. Gyllstrom, E. Jeppesen, R. Kornijow, M. R. Miracle, M. Nykanen, C. Barciss, S. Cerbin, J. Salujoe, R. Franken, D. Stephens \& B. Moss, 2003. The distribution of chydorids (Branchiopoda, Anomopoda) in European shallow lakes and its application to ecological quality monitoring. Archiv fur Hydrobiologie 156: 181-202.

Duffy, M. A., L. J. Perry \& M. Kearns, 2000. Paleogenetic evidence for a past invasion of Onondaga Lake, New York, by exotic Daphnia curvirostris using mtDNA from dormant eggs. Limnology and Oceanography 45: 1409-1414.

Duigan, C. A. \& H. H. Birks, 2000. The late-glacial and earlyHolocene Paleoecology of cladoceran microfossil assemblages in Krakenes, western Norway, with quantitative reconstruction of temperature challenges. Journal of $\mathrm{Pa}$ leolimnolgy 23: 67-76.

Eggermont, H., D. Verschuren, M. Fagot, B. Rumes, B. Van Bocxlaer \& S. Kröpelin, 2008. Aquatic community response to salinity increase in a groundwater-fed lake system during late-Holocene desiccation of the central Sahara desert. Quaternary Science Reviews 27: 2411-2425.

European Union, 2000. Directive 2000/60/EC of the European Parliament and of the Council of 23 October 2000 on establishing a framework for community action in the field of water policy. Official Journal of the European Communities L327: 1-72.

Finney, B. P., I. Gregory-Eaves, J. Sweetman, M. S. V. Douglas \& J. P. Smol, 2000. Impacts of climate change and fishing on Pacific salmon abundance over the past 300 years. Science 290: 795-799.

Fischer, J. M., M. H. Olson, C. E. Williamson, J. C. Everhart, P. J. Hogan, J. A. Mack, K. C. Rose, J. E. Saros, J. R. Stone \& R. D. Vinebrooke, 2011. Implications of climate change for Daphnia in alpine lakes: predictions from long-term dynamics, spatial distribution, and a short-term experiment. Hydrobiologia. doi:10.1007/s10750-011-0888-9.

Frey, D. G., 1960. The ecological significance of cladoceran remains in lake sediments. Ecology 41: 684-699.

Frey, D. G., 1986. Cladocera analysis. In Berglund, B. E. (ed.), Handbook of Holocene Palaeoecology and Palaeohydrology. Wiley, Chichester: 667-692.

Hairston, N. G. Jr, R. A. Van Brunt, C. M. Kears \& D. R. Engstrom, 1993. Age and survivorship of diapausing eggs in a sediment egg bank. Ecology 76: 1706-1711.

Hairston, N. G. Jr, L. J. Perry, A. J. Bohonak, M. Q. Fellows \& C. M. Kearns, 1999. Population biology of a failed invasion: paleolimnology of Daphnia exilis in upstate New York. Limnology and Oceanography 44: 477-486.

Hall, R. I. \& N. D. Yan, 1997. Comparing annual population growth estimates of the exotic invader Bythotrephes by using sediment and plankton records. Limnology and Oceanography 42: 112-120.

Hann, B. J., 1989. Methods in quaternary ecology \#6. Cladocera. Geoscience Canada 16: 17-26.
Hofmann, W., 2003. The long-term succession of highaltitude cladoceran assemblages: a 9000 year record from Sägistalsee (Swiss Alps). Journal of Paleolimnology 30: 291-296.

IPCC, 2007. Climate change 2007: The physical science basis. In Solomon, S., D. Qin, M. Manning, Z. Chen, M. Marquis, K. B. Averyt, M. Tignor \& H. L. Miller (eds), Contribution of Working Group I to the Fourth Assessment Report of the Intergovernmental Panel on Climate Change. Cambridge University Press, Cambridge.

Järvinen, M. \& K. Salonen, 1998. Influence of changing food web structure on nutrient limitation of phytoplankton in a highly humic lake. Canadian Journal of Fisheries Aquatic Science 55: 2562-2571.

Jeppesen, E., P. Nõges, T. A. Davidson, J. Haberman, T. Nõges, K. Blank, T. L. Lauridsen, M. Søndergaard, C. Sayer, R. Laugaste, L. S. Johansson, R. Berring \& S. L. Amsinck, 2011. Zooplankton as indicators in lakes-a scientific based plea for including zooplankton in the ecological assessment of lakes according to the European Water Framework Directive (WFD). Hydrobiologia. doi:10.1007/ s10750-011-0831-0.

Jeppesen, E., E. A. Madsen, J. P. Jensen \& N. J. Anderson, 1996. Reconstructing the past density of planktivorous fish and trophic structure from sediment zooplankton fossils-a surface sediment calibration data set. Freshwater Biology 36: 115-127.

Jeppesen, E., T. L. Lauridsen, S. F. Mitchell, K. Christoffersen \& C. W. Burns, 2000. Trophic structure in the pelagial of 25 shallow New Zealand lakes: changes along nutrient and fish gradients. Journal of Plankton research 22: 951-968.

Jeppesen, E., P. Leavitt, L. De Meester \& J. P. Jensen, 2001. Functional Ecology and paleolimnology: using cladoceran remains to reconstruct anthropogenic impact. Trends in Ecology and Evolution 16: 191-198.

Jeziorski, A., N. D. Yan, A. M. Paterson, A. M. DeSellas, M. A. Turner, D. S. Jeffries, B. Keller, R. C. Weeber, D. K. McNicol, M. E. Palmer, K. Melver, K. Arseneau, B. K. Ginn, B. F. Cumming \& J. P. Smol, 2008. The widespread threat of calcium decline in freshwater lakes. Science 322: 1374-1377.

Kattel, G. R. \& F. Sirocko, 2011. Palaeocladocerans as indicators of environmental, cultural and archaeological developments in Eifel maar lakes region (West Germany) during the Lateglacial and Holocene periods. Hydrobiologia. doi: 10.1007/s10750-011-0872-4.

Kattel, G. R., R. W. Battarbee, A. Mackay \& H. J. B. Birks, 2007. Are cladoceran fossils in lake sediment samples a biased reflection of the communities from which they are derived? Journal of Paleolimnology 38: 157-181.

Kattel, G. R., R. W. Battarbee, A. Mackay \& H. J. B. Birks, 2008. Recent ecological change in a remote Scottish mountain loch: an evaluation of a Cladocera-based temperature transfer-function. Palaeogeography, Palaeoclimatology, Palaeoecology 259: 51-76.

Kerfoot, W. C., 1981. Long-term replacement cycles in cladoceran communities: a history of predation. Ecology 62: 216-233.

Kerfoot, W. C., 1995. Bosmina remains in Lake Washington sediments: qualitative heterogeneity of bay environments 
and qualitative correspondence to production. Limnology and Oceanography 40: 211-225.

Kerfoot, W. C., J. A. Robbins \& L. J. Weider, 1999. A new approach to historical reconstruction: combining descriptive and experimental paleolimnology. Limnology and Oceanography 44: 1232-1247.

Korhola, A., 1999. Distribution patterns of Cladocera in subarctic Fennoscandian lakes and their potential in environmental reconstruction. Ecography 22: 357-373.

Korhola A., H. Olander \& T. Blom, 2000. Cladoceran and chironomid assemblages as quantitative indicators of water depth in subarctic Fennoscandian lakes. Journal of Paleolimnology 24: 43-54.

Korhola, A. \& M. Rautio, 2001. Cladocera and other branchiopod crustaceans. In Smol, J. P., H. J. B. Birks \& W. M. Last (eds), Tracking Environmental Change Using Lake Sediments 4. Zoological Indicators. Kluwer Academic Publishers, Dordrecht, The Netherlands: 5-41.

Korhola, A., M. Tikkanen \& J. Weckström, 2005. Quantification of Holocene lake-level changes in Finnish Lapland using a Cladocera-lake depth transfer model. Journal of Paleolimnology 34: 175-190.

Korosi, J. B., A. Jeziorski \& J. P. Smol, 2011. Using morphological characters of subfossil daphniid postabdominal claws to improve taxonomic resolution within species complexes. Hydrobiologia. doi:10.1007/s10750-011-0779-0.

Korosi, J. B. \& J. P. Smol, 2011. Distribution of cladoceran assemblages across environmental gradients in Nova Scotia (Canada) lakes. Hydrobiologia 663: 83-99.

Korponai J., E. K. Magyari, K. Buczkó, S. Iepure, T. Namiotko, D. Czakó, C. Kövér \& M. Braun, 2011a. Cladoceraresponse to Late Glacial to Early Holocene climate change in a South Carpathian mountain lake. Hydrobiologia. doi: 10.1007/s10750-011-0881-3.

Korponai J., K. A. Varga, T. Lengré \& I. Papp, 2011b. Paleolimnological reconstruction of trophic state in the Lake Balaton using cladocera remains. Hydrobiologia. doi: 10.1007/s10750-011-0898-7.

Kultti, S., L. Nevalainen, T. P. Luoto \& Kaarina Sarmaja-Korjonen, 2011. Subfossil chydorid (Cladocera, Chydoridae) ephippia as paleoenvironmental proxies-evidence from boreal and subarctic lakes. Hydrobiologia. doi:10.1007/ s10750-011-0869-z.

Kurek, J., J. B. Korosi, A. Jeziorski \& J. P. Smol, 2010. Establishing reliable minimum count sizes for cladoceran subfossils sampled from lake sediments. Journal of Paleolimnology 44: 603-612.

Limburg, P. A. \& L. J. Weider, 2002. 'Ancient' DNA in the resting egg bank of a microcrustacean can serve as a paleolimnological database. Proceedings of the Royal Society of London Series B-Biological Sciences 269: 281-287.

López-Blanco, C., M. R. Miracle \& E. Vicente, 2011. Cladoceran assemblages in a karstic lake as indicators of hydrological alterations. Hydrobiologia. doi:10.1007/s10750011-0876-0.

Lotter, A. F., H. J. B. Birks, W. Hofmann \& A. Marchetto, 1997. Modern diatom, cladocera, chironomid and chrysophyte cyst assemblages as quantitative indicators for the reconstruction of past environmental conditions in the Alps. I. Climate. Journal of Paleolimnology 18: 395-420.
Lotter, A. F., H. J. B. Birks, U. Eicher, W. Hofmann, J. Schwander \& L. Wick, 2000. Younger Dryas and Allerød summer temperatures at Gerzensee (Switzerland) inferred from fossil pollen and cladoceran assemblages. Palaeogeography, Palaeoclimatology and Palaeoecology 159: 349-361.

Luoto, T. P., L. Nevalainen, S. Kultti \& K. Sarmaja-Korjonen, 2011. An evaluation of the influence of water depth and river inflow on quantitative Cladocera-based temperature and lake level inferences in a shallow lake. Hydrobiologia. doi:10.1007/s10750-011-0801-6.

Mergeay, J., D. Verschuren \& L. De Meester, 2006. Invasion from an asexual American water flea clone throughout Africa and rapid displacement of a native sibling species. Proceedings of the Royal Society B. Biological Sciences 273: 2839-2844.

Mergeay, J., J. Vanoverbeke, D. Verschuren \& L. De Meester, 2007. Extinction, recolonization and dispersal through time in a planktonic crustacean. Ecology 88: 3032-3043.

Milecka K., G. Kowalewski \& K. Szeroczyńska, 2011. Climaterelated changes during the Late Glacial and early Holocene in northern Poland, as derived from the sediments of Lake Sierzywk. Hydrobiologia. doi:10.1007/s10750-0110874-2.

Nevalainen, L., 2011. Intra-lake heterogeneity of sedimentary cladoceran (Crustacea) assemblages forced by local hydrology. Hydrobiologia. doi:10.1007/s10750-011-0707-3.

Nevalainen, L., T. P. Luoto, S. Levine \& M. Manca, 2011a. Modern and pre-industrial age distributions of Cladocera in Italian and Swiss Alpine lakes. Hydrobiologia. doi:10. 1007/s10750-011-0802-5.

Nevalainen, L., K. Sarmaja-Korjonen \& T. P. Luoto, 2011 b. Sedimentary Cladocera as indicators of past water-level changes in shallow northern lakes. Quaternary Research 75: 430-437.

Nykänen, M., K. Vakkilainen, M. Liukkonen \& T. Kairesalo, 2009. Cladocera remains in lake sediments: a comparison between plankton counts and sediment records. Journal of Paleolimnology 42: 551-570.

Paterson, M., 1994. Invertebrate predation and seasonal dynamics of microcrustacea in the littoral zone of fishless lakes. Archiv fur Hydrobiologie Supplement 99: 1-36.

Pollard, H. G., J. K. Colbourne \& W. B. Keller, 2003. Reconstruction of centuries-old Daphnia communities in a lake recovering from acidification and metal contamination. Ambio 32: 214-218.

Rautio, M., S. Sorvari \& A. Korhola, 2000. Diatom and crustacean zooplankton communities, their seasonal variability and representation in the sediments of subarctic Lake Saanajärvi. Journal of Limnology 59: 81-96.

Rull, V., J. A. Lopez-Saez \& T. Vegas-Vilarrubia, 2008. Contribution of non-pollen palynomorphs to the paleolimnological study of a high-altitude Andean lake (Laguna Verde Alta, Venezuela). Journal of Paleolimnology 40: 399-411.

Rumes, B., H. Eggermont \& D. Verschuren, 2011. Distribution and faunal richness of Cladocera in western Uganda crater lakes. Hydrobiologia. doi:10.1007/s10750-011-0829-7.

Sarmaja-Korjonen, K. \& H. Hyvärinen, 1999. Cladoceran and diatom stratigraphy of calcerous lake sediments form Kuusamo, NE Finland. Indications of Holocene lake-level changes. Fennia 177: 55-70. 
Shumate, B. C. A., C. L. A. Schelske, T. L. A. Crisman \& W. F. A. Kenney, 2002. Response of the cladocera community to trophic state change in Lake Apopka, Florida. Journal of Paleolimnology 27: 71-77.

Siitonen S., M. Väliranta, J. Weckström, S. Juutinen \& A. Korhola, 2011. Comparison of Cladocera-based waterdepth reconstruction against other types of proxy data in Finnish Lapland. Hydrobiologia. doi:10.1007/s10750011-0885-z.

Szeroczyńska, K. \& K. Sarmaja-Korjonen, 2007. Atlas of Subfossil Cladocera from Central and Northern Europe. Friends of the Lower Vistula Society, Świecie.
Urabe, J., J. J. Elser, M. Kyle, T. Yoshida, T. Sekino \& Z. Kawabata, 2002. Herbivorous animals can mitigate unfavourable ratios of energy and material supplies by enhancing nutrient recycling. Ecology Letters 5: 177-185.

Van Damme, K \& H. Eggermont, 2011. The Afromontane Cladocera (Crustacea: Branchiopoda) of the Rwenzori (Uganda-D. R. Congo): ecology, biogeography and taxonomy including the description of Alona sphagnophila $\mathrm{n}$. sp. Hydrobiologia. doi:10.1007/s10750-011-0892-0. 